\title{
Editor's Note: Journal of Forensic Research (Volume 7 Issue 3)
}

\section{Harvey JM Hou*}

Forensic Science Program, Department of Physical Sciences, Alabama State University, Alabama, USA

*Corresponding author: Harvey JM Hou, Forensic Science Program, Department of Physical Sciences, Alabama State University, Montgomery, Alabama 36104, USA, Tel: (334) 229-5121; Email: hhou@alasu.edu

Received: July 21, 2016; Accepted: July 25, 2016; Published: July 30, 2016

Copyright: (C) 2016 Hou HJM. This is an open-access article distributed under the terms of the Creative Commons Attribution License, which permits unrestricted use, distribution, and reproduction in any medium, provided the original author and source are credited.

Citation: Hou HJM (2016) Editor's Note: Journal of Forensic Research (Volume 7 Issue 3). J Forensic Res 7: e118. doi:10.4172/2157-7145.1000e118

\section{Editor Note}

Forensic investigations, which will provide solid scientific explanation of forensic evidences, are crucial to the solution of the dispute of two parties in civil cases or to the resolution of the crimes in forensic community. The updated and emerging technology is vital in forensic investigations.

As we know, the early forensic technology involves the microscope and spectrophotometer. Currently more and more modern technology has been applied in forensic investigations. The modern technology includes, not limited to, UV-visible spectroscopy, fluorescence, Fourier transform infrared spectroscopy, Raman spectroscopy, high performance liquid chromatograph, mass spectrometry, nuclear magnetic resonance spectroscopy, scanning electron microscopyenergy dispersive spectroscopy, immunoassay, 13 STR DNA profiling, and mitochondria DNA analysis [1-2]. As the forensic evidences are diverse and involving examination of finger-marks, glasses, soil, questioned document, fibers, paints, arson, firearm, tool marks, explosives, drug, and DNA samples. In addition, acoustic analysis and video analysis are considered for forensic investigations. Microbial forensics and nanoforensics are being emerging for potential applications in forensic sciences [3-6].

The Journal of Forensic Research (JFR) is an international, Open Access, and peer reviewed journal that publishes scientific articles related to the forensic discoveries, to name a few, such as forensic genetics, DNA analysis, drug identification, finger-printing examination, environmental forensics, and criminal cases. The current issue, Volume 7, Issue 3 published three research articles and two case reports.

Mathur et al., in their research have evaluated the amount of variation in the fundamental voice (F0) and have evaluated the variation of disguise and normal speech with the help of samples taken from speakers. Their studies concluded that F0 value of the normal voice quality of the speakers decreases with constriction of tract, pinching of nostrils, infection, changing accent/tone, covering mouth, obstacle in mouth, throat lowering of pitch, pulling the cheeks, lowering the voice as whisper and when affected with cold. Authors have suggested that these parameters may help in determining the reliability and validity of the fundamental voice under different disguised conditions [7]. In the research article Manoel et al. have analyzed the role of alcohol consumption in the crimes or accidents, leading to death. Authors could find significant positive correlation between alcohol consumption and violent deaths [8]. Pandey et al. reported the case of man-eating leopard in which the authors have described the process of individualization of human conflicting wild animals (leopard) using modern molecular genetic techniques. Authors have suggested that the methodology used in this case should be accurate in identifying the conflicting nature of the wild animals [9]. Khairkaret al. have analyzed the importance of micro spectrophotometer and van den Hondelet al have discussed the role of the video spectral comparator in analyzing the fraud cases and question document and examination of ten-year old mummified corpse [10-11].

In summary, the emerging and the state-of-the-art techniques is extremely valuable in forensic investigations, for example, forensic DNA profiling in identification of suspect in criminal cases [12]. As forensic science is the applied science using scientific techniques to law, it is increasingly clear that forensic technology is critical to the criminal and civil laws in social justice.

\section{References}

1. Saferstein R (2011) Criminalistics. (10th edn), Prentice Hall, New Jersey, USA.

2. Siegel J (2015) Forensic Chemistry: Fundamentals and Applications. John Wiley \& Sons, New Jersey, United States.

3. Hou HJM (2015) Nanoforensics: Forensic application of nanotechnology in illicit drug detection. J Forensic Res 6: 5.

4. Hou HJM (2014) Signature analysis of bacteria, toxins and anthrax in microbial forensics. J Forensic Res 5: 6.

5. Hou HJM (2013) Analysis of botulinum neurotoxin detection by mass spectrometry in forensic samples. J Forensic Res 4: 185.

6. Hou HJM, Scissum-Gunn K, Wu H, Akujuobi C (2012) Microbial forensics: An emerging field and a national need. Air Water Borne Dis 1: e107.

7. Mathur S, Choudhary BSK, Vyas CJM (2016) Effect of Disguise on Fundamental Frequency of Voice. J Forensic Res 7: 327.

8. Manoel ESM, Stephane ML (2016) Alcohol Influence in Violent Deaths. J Forensic Res 7: 328.

9. Pandey P, Sharma V, Singh SK, Goel D, Goyal SP (2016) Curtailing HumanLeopard Conflict Using Wildlife Forensics: A Case Study from Himachal Pradesh, India. J Forensic Res 7: 331.

10. Khairkar SR, Gaikawad SV, Kokare RN, Daundkar BB (2016) Forensic Discrimination Potential of Video Spectral Comparator and Micro Spectrophotometer in Analyzing Question Document and Fraud Cases in India. J Forensic Res 7: 329.

11. van den Hondel KE, Buster M, Bender PP, Reijnders U (2016) Ten-YearOld Mummified Corpse Found in Domestic Setting in Rotterdam the Netherlands. J Forensic Res 7: 330.

12. Butler JM (2010) Forensic DNA Typing. (3rd edn), Elsevier, Amsterdam, Netherlands. 